\title{
KERAGAMAN JENIS SERANGGA DIURNAL DI KAWASAN KAMPUS UNIVERSITAS MUHAMMADIYAH ACEH SEBAGAI MEDIA PEMBEJARAN ZOOLOGI INVERTEBRATA
}

\section{DIURNAL INSECT TYPES IN THE MUHAMMADIYAH UNIVERSITY CAMPUS AREA AS A MEDIA FOR INVERTEBRATE ZOOLOGY LEARNING}

\author{
Julia Rahmi Yusuf ${ }^{1}$, Ulia Hanum ${ }^{2}$, Qurratu Aini ${ }^{3}$, Suwarniati $^{4}$, Safryadi $A^{5}$ \\ 1, 2,3,4 Program Studi Tadris Biologi, Fakultas Agama Islam, Universitas Muhammadiyah \\ Aceh, Banda Aceh, Indonesia \\ ${ }^{5}$ Program Studi Pendidikan Biologi, Fakultas Tarbiyah, Universitas UIN-Arraniry, Banda \\ Aceh, Indonesia \\ *Email: qurratu.aini@unmuha.ac.id
}

\begin{abstract}
ABSTRAK
Penelitian ini dilaksanakan di kawasan kampus Universitas Muhammadiyah Aceh pada bulan Mei sampai Agustus 2015 yang bertujuan untuk mengetahui jenis serangga diurnal, tingkat keragaman dan menjadikan jenis serangga diurnal sebagai media pembelajaran zoologi invertebrata. Pengambilan sampel penelitian dilakukan dengan menggunakan insect net, pitfall trap, areal bait trap, dan aspirator pada tiga stasiun pengamatan yang telah ditentukan. Analisis data dilakukan dengan cara mendeskripsikan setiap jenis serangga diurnal yang ditemukan. Selanjutnya untuk mengetahui tingkat keragaman jenis serangga diurnal di kampus Universitas Muhammadiyah Aceh digunakan indeks keragaman Shannon Wiener (H'). Hasil penelitian di peroleh serangga diurnal sebanyak 1580 individu yang terdiri dari 8 ordo, 17 familia dengan 26 jenis. 26 jenis serangga diurnal masing - masing terdiri masing masing 7 jenis dari ordo Hymenoptera famili Formicidae, Apidae, dan Perilampidae, 4 jenis ordo Hemiptera famili Lygaeidae, Alydidae, Coreidae dan Pentatomidae, 2 jenis dari ordo Diptera famili Calliphoridae dan Muscidae, 2 jenis dari ordo Coleoptera famili Coccinellidae, 4 jenis dari ordo Lepidoptera famili Nymphalidae dan Pieridae , 3 ordo jenis dari Orthoptera famili Acrididae dan Tetrigidae, 1 jenis dari ordo Mantodea famili Mantodidae dan 3 jenis dari ordo Odonata famili Libellulidae dan Coenagrionidae. Hasil analisis indeks keragaman menunjukkan nilai 1,68 yang berarti tingkat keragaman serangga diurnal di kawasan kampus Universitas Muhammadiyah Aceh tergolong sedang, dengan indeks kemerataan 0,51 artinya bahwa distribusi jumlah individu setiap jenis serangga diurnal di masing - masing stasiun penelitian relatif terdistribusi secara merata.
\end{abstract}

Kata kunci: Keragaman, Serangga Diurnal, Media Pembelajaran

\section{ABSTRACT}

This research was conducted in the campus area of the University of Muhammadiyah Aceh in August 2015 which aims to determine the types of diurnal insects, the level of diversity and make the types of diurnal insects as learning media for invertebrate zoology. Sampling was carried out using insect nets, pitfall traps, bait trap areas, and aspirators at three predetermined observation stations. Data analysis was carried out by describing each type 
Jurnal Jeumpa, 8 (2) Juli-Desembaer 2021

of diurnal insect found. Furthermore, to determine the level of diversity of diurnal insect species on the University of Muhammadiyah Aceh campus, the Shannon Wiener $\left(H^{\prime}\right)$ diversity index was used. The results of the study obtained 1580 diurnal insects consisting of 8 orders, 17 families with 26 species. 26 types of diurnal insects, each consisting of 7 species from the order Hymenoptera, families Formicidae, Apidae, and Perilampidae, 4 species from the order Hemiptera, families Lygaeidae, Alydidae, Coreidae and Pentatomidae, 2 species from the order Diptera, families Calliphoridae and Muscidae, 2 species from the order Coleoptera, the family Coccinellidae, 4 species from the order Lepidoptera, the families Nymphalidae and Pieridae, 3 species from the order Orthoptera, the families Acrididae and Tetrigidae, 1 species from the order Mantodea, the family Mantodidae and 3 species from the order Odonata, the families Libellulidae and Coenagrionidae. The results of the diversity index analysis showed a value of 1.68, which means that the level of diversity of diurnal insects in the Muhammadiyah Aceh University campus area is moderate, with an evenness index of 0.51 meaning that the distribution of the number of individuals for each type of diurnal insect in each research station is relatively evenly distributed.

Keywords: Diversity, Diurnal Insects, Learning Media

\section{PENDAHULUAN}

Keragaman merupakan kata yang tepat untuk menggambarkan keadaan bermacam-macam suatu benda yang dapat terjadi akibat adanya perbedaan dalam hal ukuran, bentuk, tekstur danlainnya. Pada dasarnya semua makhluk hidup memiliki keragaman. Keragaman makhluk hidup dapat terlihat dengan adanya persamaan ciri antar makhluk hidup. Keragaman ada yang terjadi secara alami dan ada juga yang terjadi secara

buatan. Keragaman alami merupakan kerag aman yang terjadi akibat adaptasi atau penyesuaian diri setiap individu dengan ligkungannya (Supriyono, 2011).

Keragaman hewan menunjukkan berbagai variasi dalam bentuk, struktur tubuh, warna, jumlah, dan sifat lainnya di suatu daerah. Sumber alam hayati merupakan bagian dari mata rantai tatanan lingkungan hidup, yang menjadikan lingkungan ini hidup dan mampu menghidupkan dari generasi ke generasi. Kita patut bersyukur kepada Tuhan, karena alam semesta ini diserahkan kepada manusia untuk diambil hikmahnya, diolah, dimanfaatkan secara lestari keberadaannya (Supriyono, 2011).

Suatu komunitas bukan hanya merupakan pengelompokan secara serampangan hewan dan tumbuhan yang hidup secara mandiri satu sama lain namun mengandung komposisi kekhasan taksonomi, dengan pola hubungan tropik dan metabolik yang tertentu (Michael, 1994).

Tiap-tiap hewan memerlukan alam sekitar untuk kehidupannya yang berbeda- 
beda. Serangga merupakan invertebrata yang hidup ditempat yang kering dan dapatterbang. Kemampuan hidup ditempat yang kering, tubuh terbungkus oleh kitin, menyebabkan serangga dapat menyesuaikan diri, memiliki daya adaptasi yang besar terhadap lingkungan (Jasin, 1987).

Serangga menarik untuk diamati karena jenisnya yang cukup banyak dan juga karena perannya dalam kehidupan. Dari sekian banyak jenis hewan yang ada dipermukaan bumi, ternyata tiga perempat bagian adalah serangga. Dari jumlah tersebut lebih dari 750.000 jenis telah berhasil diketahui dan diberi nama (Jumar, 2000).

Ilmu pengetahuan dan teknologi yang berkembang pesat memunculkan tuntutan baru dalam segala aspek kehidupan, termasuk sistem pendidikan nasional diantaranya menyangkut pembaharuan pendidikan yang didalamnya termasuk pembaharuan kurikulum yaitu diversifikasi kurikulum untuk melayani peserta didik dan potensi daerah yang beragam (Hamalik, 1989).

Salah satu prinsip pengajaran modern adalah penggunaan media pembelajaran yang bervariasi dan sesuai untuk memudahkan siswa dalam menerima materi pembelajaran. Perkembangan dalam dunia pendidikan yang menunjukkan perkembangan pesat harus mampu melibatkan komponen - komponen
Jurnal Jeumpa, 8 (2) Juli-Desembaer 2021 pendidikan dalam proses pembelajaran, termasuk lingkungan sekitar. Dengan demikian pemamfaatan media lingkungan dalam pembelajaran dapat memberi hasil belajar siswa yang lebih baik.

Hasil belajar tersebut diperoleh setelah kegiatan pembelajaran berlangsung, yang biasanya dapat diketahui setelah evaluasi dilakukan. Namun, harapan semua pihak, menginginkan hasil belajar yang efektif.

Potensi dapat ditingkatkan atau ditumbuh kembangkan melalui berbagai cara. Pencapaiaan tujuan tersebut, mahasiswa mempunyai tiga media utama yang dapat menjadi penunjang dalam pembelajaran atau praktikum, yaitu modul sebagai bahan / materi pembelajaran, alat dan bahan praktikum sebagai penunjang praktik dan lingkungan sekitar sebagai labolatorium nyata. Penggunaan media lingkungan yang ada disekitar akan membantu mahasiswa untuk menyatukan materi pelajaran dengan bukti yang ada di alam sekitar, sehingga siswa dapat mengaplikasikan ilmunya secara nyata.

Pembelajaran zoologi invertebrata di kampus Universitas Muhammadiyah Aceh selama ini hanya terpaku media dari lingkungan luar kampus, sementara dilingkungan kampus sendiri, masih dapat dipergunakan perkarangannya untuk membantu praktikum perkuliahan khususnya filum Arthropoda kelas Insecta. 
Berdasarkan hasil observasi pra penelitian belum ada data yang meneliti tentang keragaman jenis serangga yang ada di

\section{METODE PENELITIAN}

Penelitian ini dilakukan pada bulan Mei sampai dengan Agustus 2015 di kawasan kampus Universitas
Jurnal Jeumpa, 8 (2) Juli-Desembaer 2021 kawasan kampus UNMUHA baik serangga diurnal maupun serangga nokturnal.

Muhammadiyah Aceh beralamat Jalan Muhammadiyah 91, Desa Bathoh Lueng Bata, Banda Aceh.

a. Alat dan Bahan

Tabel 1. Alat yang digunakan dalam penelitian

\begin{tabular}{|c|c|c|c|}
\hline No & Nama Alat & Spesifikasi & Fungsi \\
\hline 1. & Jaring Serangga & - & Menangkap serangga \\
\hline 2. & Botol & - & menampung serangga yang ditemukan. \\
\hline 3. & Kamera & Sony DSC-W810. & $\begin{array}{l}\text { Dokumentasikan jenis-jenis serangga yang } \\
\text { diperoleh }\end{array}$ \\
\hline 4. & Pinset & $\begin{array}{l}\text { Hanlim JMC } \\
\text { Stainless }\end{array}$ & Menjepit hewan yang didapat. \\
\hline 5. & Thermo-Hygro & Dekto 637 & $\begin{array}{l}\text { Mengukur suhu udara dan kelembaban } \\
\text { udara }\end{array}$ \\
\hline 6. & Alat tulis menulis & - & Mencatat Hasil Penelitian \\
\hline 7. & Aerial bait trap & - & Perangkap serangga pohon \\
\hline 8. & Aspirator & - & Perangkap serangga pohon \\
\hline 9. & Pitfall trap & - & Perangkap serangga permukaan tanah \\
\hline
\end{tabular}

Bahan yang digunakan dalam penelitian ini memakai alkohol berfungsi untuk membuat awetan serangga yang diidentifikasi dan gula berfungsi untuk umpan serangga.

\section{b. Objek Penelitian}

Objek penelitian ini adalah seluruh serangga di kawasan kampus Universitas Muhammadiyah Aceh yang terdapat didalam stasiun pengamatan.

\section{c. Rancangan Penelitian}

Metode yang digunakan adalah metode eksploratif dengan teknik porpusive sampling yaitu dengan cara pengambilan sampel berdasarkan daerah yang telah ditentukan langsung dimana terdapatnya jenis serangga tersebut. Penelitian eskploratif menutut Subyantoro yaitu "penelitian penjelajahan yang bertujuan untuk mencari dan menemukan masalah baru atau kekurangan dari pengetahuan, baik yang belum atau yang sudah ada" Penelitian ini dilakukan dengan observasi yaitu mengamati langsung kelapangan serta pengambilan sampel dengan menggunakan jala serangga (insect net), aerial bait trap, aspirator dan pit fall 
trap dalam unit - unit (stasiun pengamatan) yang di kawasan kampus Universitas Muhammadiyah Aceh. Stasiun pengamatan di bagi tiga stasiun yaitu stasiun I di lingkungan dalam kampus, stasiun ke II di lingkungan luar kampus bagian Selatan dan stasiun ke III lingkungan luar kampus bagian Timur.

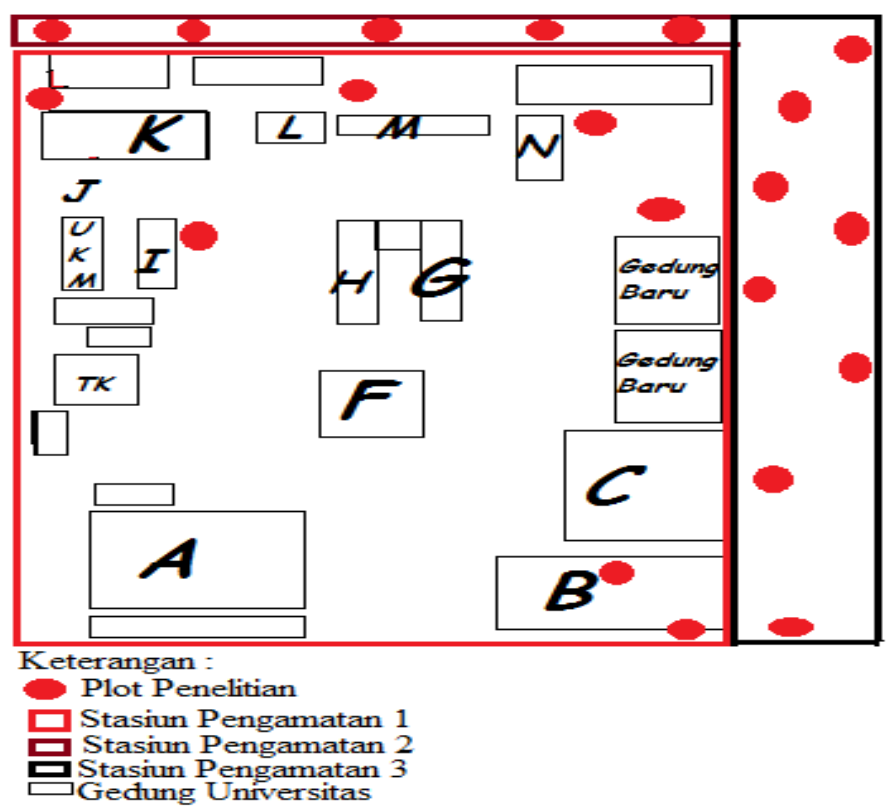

Gambar 1. Stasiun Pengamatan

\section{d. Teknik Pengumpulan Data}

Untuk memperoleh data yang objektif dan dapat di pertanggung jawabkan kebenarannya maka dingunakan cara-cara sebagai berikut:

\section{Observasi}

Observasi akan dilakukan untuk pencatatan secara sistematik mengenai hal - hal yang perlu diselidiki dan bertujuan untuk memperkuat penjelasan serta keterangan secara langsung terhadap objek yang diteliti dengan melakukan pengamatan kelapangan untuk melihat gambaran langsung objek penelitian secara mendetail khususnya semua jenis serangga dan faktor fisik lingkungan di unit - unit lokasi penelitian terhadap gejala - gejala yang ada dilapangan.

\section{Pengambilan Sampel Serangga}

Penelitian ini hanya mengumpulkan serangga yang aktif pada siang hari dari jam 07.00 WIB 18.00 , untuk tujuan tersebut jenis - jenis peralatan sederhana yang diperlukan antara lain :

1) Jaring serangga udara (Insect Net) 
Jurnal Jeumpa, 8 (2) Juli-Desembaer 2021

Jaring serangga digunakan untuk pengambilan serangga udara. Jaring serangga digunakan untuk menangkap serangga yang aktif terbang. Jaring serangga dibuat dari bahan yang ringan dan kuat, yaitu kain kasa dan blacu. Panjang tangkai jaring sekitar $75-100$ $\mathrm{cm}$. Mulut jaring terbuka dengan garis tengah $30 \mathrm{~cm}$. Bingkai lingkaran terbuat dari kawat yang keras dan kuat. Panjang kantong kain kasa sekitar dua kali panjang garis tengah lingkaran mulut jaring. Jaring serangga dapat digunakan dengan dua cara yaitu mengayunkan pada serangga dan menyapukan disekitar pertanaman (Jumar, 2000).

2) Sumur perangkap (Pitfall trap)

Serangga permukaan tanah di ambil dengan memakai sumur perangkap. Perangkap ini digunakan untuk menangkap serangga - serangga yang berjalan di atas permukaan tanah. Pitfall trap digunakan dengan cara membenamkan kalengke dalam tanah hingga mulut kaleng rata dengan permukaan tanah, bagian dalam kaleng di beri larutan pengawet dan memberikan umpan untuk menarik kedatangan serangga kemudian ditutup dengan pelindung untuk mencegah masuknya air hujan (Jumar, 2000).

Plot pitfall trap di letakkan sebanyak 20 yang terdiri dari 7 plot di stasiun pertama, 8 plot di stasiun kedua dan 5 plot di stasiun ke 3. Setiap plot berjarak 1 meter dari titik utama plot, sedangkan jarak antar plot di sesuaikan dengan keadaan lingkungan mewakili setiap lokasi yang ditentukan.

Pada setiap plot di letakkan 5 sumur perangkap yang di isi larutan alkohol untuk awetan dan gula untuk menarik perhatian serangga. Larutan yang di isi setiap sumur perangkap setengah dari tinggi botol perangkap tersebut.

3) Alat penghisap (Aspirator)

Aspirator merupakan alat untuk mengumpulkan serangga - serangga kecil dan tidak begitu aktif bergerak dengan cara menghisapnya. Alat ini di pakai untuk mengumpulkan serangga yang diperlukan dalam keadaan hidup (Jumar, 2000).

4) Aerial bait trap

Perangkap ini berukuran relatif kecil, dan biasanya terbuat dari dua buah toples plastik yang berdiameter 15 $\mathrm{cm}$ dengan bagian tutup yang berbulir. Kedua toples tersebut diletkkan berhadapan pada bagian mulutnya. Tutup - tutup toples tersebut diberi lubang bulat dan besar. Pada bagian dalam tutup toples ditempel corong yang terbuat dari kawat / kain kasa. 
Jurnal Jeumpa, 8 (2) Juli-Desembaer 2021

Bagian dasar toples yang diberi lubang

-lubang kecil sebagai pentilasi untuk mencegah kondensasi dan membiarkan serangga yang terperangkap masih hidup. Umpan sebagai penarik

\section{e. Teknik Analisis Data}

Analisis data serangga diurna menggunakan Indeks Shannon Wiener untuk mengetahui keragaman jenis dengan rumus:

$\mathrm{H}^{\prime}=-\sum p i \cdot \ln p i, p i=\mathrm{ni} / \mathrm{N}$

Nilai keragaman berdasarkan Indeks Shannon Wiener dikelompokkan

HASIL DAN PEMBAHASAN

\section{A. Jenis Serangga Diuranal Di Kawasan Kampus UNMUHA}

Pengumpulan data serangga dilakukan dengan empat cara yaitu dengan menggunkan jala serangga (insect net), kedatangan serangga diletakkan di dalam stoples bawah. Beberapa jenis bahan yang digunakan sebagai umpa yang di gantung pada pohon ((Jumar, 2000).

dalam tiga kriteria, yaitu: apabila $H^{\prime}=\leq$ 1,5 maka keragaman rendah. Selanjutnya apabila nilai $\mathrm{H}^{\prime}=1,5-3,5$ maka keragaman sedang dan apabila nilai $\mathrm{H}^{\prime}$ berada pada $\geq 3,5$ maka keragaman adalah tinggi. Sedangkan untuk kemerataan jenis dapat menggunakan rumus sebagai berikut:

$$
J^{\prime}=\frac{H^{\prime}}{\ln S} \text { atau } E^{\prime}=\frac{H^{\prime}}{\ln S}
$$

perangkap sumur (pitfall trap), areal bait trap dan alat hisap (aspirator) di peroleh serangga diurnal sebanyak 1580 individu yang terdiri dari 8 Ordo, 17 familia dengan 26 jenis. Jenis serangga diurnal yang didapatkan dari seluruh titik pengamatan adalah

Tabel 2. Jumlah Serangga Keseluruhan

\begin{tabular}{cccllcc}
\hline \multirow{2}{*}{ No } & \multirow{2}{*}{ Ordo } & \multirow{2}{*}{ Familia } & \multicolumn{3}{c}{ Jenis } & \multirow{2}{*}{ Jumlah } \\
\cline { 4 - 6 } & & & \multicolumn{1}{c}{ Nama Umum } & Nama Ilmiah & \\
\hline $\mathbf{1}$ & $\mathbf{2}$ & \multicolumn{1}{c}{$\mathbf{4}$} & \multicolumn{1}{c}{$\mathbf{5}$} & $\mathbf{6}$ \\
\hline 1 & Hymenoptera & Formicidae & Semut Gula & Pheidole Sp. & 363 \\
2 & Hymenoptera & Formicidae & Semut Hitam 1 & Iridomermex Sp. & 758 \\
3 & Hymenoptera & Formicidae & Semut Api & Solenopsis Sp. & 110 \\
4 & Hymenoptera & Formicidae & Semut Hitam 2 & Formica Sp. & 129 \\
5 & Hymenoptera & Formicidae & Semut Gila & Paratrecina & 72 \\
& & & & longicornis & \\
6 & Hymenoptera & Apidae & Lebah & Apis andreniformis & 12
\end{tabular}


Jurnal Jeumpa, 8 (2) Juli-Desembaer 2021

\begin{tabular}{|c|c|c|c|c|c|}
\hline 7 & Hymenoptera & Perilampidae & Tawon & Perilampidae 1 & 3 \\
\hline 8 & Hemiptera & Alydidae & Walang sangit & Leptocorisa acuta & 12 \\
\hline 9 & Hemiptera & Coreidae & Kutu ubi jalar & Physomerus grossipes & 2 \\
\hline 10 & Hemiptera & Lygaeidae & Bapak Pucung & Dysdercuc cingulatus & 14 \\
\hline 11 & Hemiptera & Pentatomidae & Kepik hijau & Nezara viridula & 1 \\
\hline 12 & Lepidoptera & Nymphalidae & $\begin{array}{l}\text { Kupu - kupu } \\
\text { Orange }\end{array}$ & Acraea violae & 30 \\
\hline 13 & Lepidoptera & Nymphalidae & $\begin{array}{l}\text { Kupu }- \text { kupu } \\
\text { Biduri }\end{array}$ & Danaus chrysippus & 19 \\
\hline 14 & Lepidoptera & Nymphalidae & $\begin{array}{l}\text { Kupu - kupu } \\
\text { Putih Hijau }\end{array}$ & Appias olferma & 2 \\
\hline 15 & Lepidoptera & Nymphalidae & $\begin{array}{l}\text { Kupu - kupu } \\
\text { Putih Hitam }\end{array}$ & Appias libythea & 1 \\
\hline 16 & Orthoptera & Acrididae & Belalang Coklat & Locusta migratoria & 13 \\
\hline 17 & Orthoptera & Acrididae & Belalang kayu & Valanga nigricornis & 5 \\
\hline 18 & Orthoptera & Tettrigidae & $\begin{array}{l}\text { Belalang } \\
\text { Runcing }\end{array}$ & Tettrigridae lateralis & 2 \\
\hline 19 & Odonata & Libellulidae & Capung Sawah & Crocothemis servilia & 4 \\
\hline 20 & Odonata & Libellulidae & Capung Hijau & Orthertrum Sabina & 7 \\
\hline 21 & Odonata & $\begin{array}{l}\text { Coenagrioni } \\
\text { dae }\end{array}$ & Capung Jarum & Ischnura senegalensis & 7 \\
\hline 22 & Diptera & Calliphoridae & Lalat Hijau & Lucilia sericata & 2 \\
\hline 23 & Diptera & Muscidae & Lalat Rumah & Musca domestica & 4 \\
\hline 24 & Coleoptera & Coccinelidae & $\begin{array}{l}\text { Kumbang } \\
\text { koksi } 1\end{array}$ & $\begin{array}{l}\text { Coccinella } \\
\text { transversalis }\end{array}$ & 4 \\
\hline 25 & Coleoptera & Coccinelidae & $\begin{array}{l}\text { Kumbang } \\
\text { koksi } 2\end{array}$ & Coccinella Sp. & 1 \\
\hline 26 & Mantodea & Mantodae & $\begin{array}{l}\text { Belalang } \\
\text { sembah }\end{array}$ & Hierudula vitrea & 3 \\
\hline & Jumlah & & & & 1580 \\
\hline
\end{tabular}

\section{B. Keragaman Serangga Diurnal Di Kawasan Kampus UNMUHA}

Nilai keragaman serangga diurnal dihitung dengan menggunakanan rumus indeks Shannon Wiener.

Tabel 3. Analisis Data Serangga Diurnal

\begin{tabular}{llcccc}
\hline $\mathbf{N o}$ & \multicolumn{1}{c}{ Spesies } & $\mathbf{N i}$ & $\mathbf{P i}$ & $\mathbf{l n P i}$ & $\mathbf{P i} \mathbf{l n} \mathbf{P i}$ \\
\hline $\mathbf{1}$ & $\mathbf{2}$ & $\mathbf{3}$ & $\mathbf{4}$ & $\mathbf{5}$ & $\mathbf{6}$ \\
\hline 1 & Pheidole Sp. & 363 & 0.230 & -1.46 & -0.335 \\
2 & Iridomyrmex Sp. & 758 & 0.480 & -0.73 & -0.350 \\
3 & Solenopsis Sp. & 110 & 0.070 & -2.65 & -0.184 \\
4 & Formica Sp. & 129 & 0.082 & -2.5 & -0.204 \\
5 & Paratrecina longicornis & 72 & 0.046 & -3.07 & -0.140 \\
6 & Apis andreniformis & 12 & 0.008 & -4.82 & -0.037 \\
7 & Perilampidae 1 & 3 & 0.002 & -6.21 & -0.012 \\
8 & Leptocorisa acuta & 12 & 0.008 & -4.82 & -0.037
\end{tabular}


Jurnal Jeumpa, 8 (2) Juli-Desembaer 2021

\begin{tabular}{clcccc}
9 & Physomerus grossipes & 2 & 0.001 & -6.9 & -0.009 \\
10 & Dysdercuc cingulatus & 14 & 0.009 & -4.71 & -0.042 \\
11 & Nezara viridula & 1 & 0.001 & -6.9 & -0.004 \\
12 & Acraea violae & 30 & 0.019 & -3.96 & -0.075 \\
13 & Danaus chrysippus & 19 & 0.012 & -4.42 & -0.053 \\
14 & Appias olferma & 2 & 0.001 & -6.9 & -0.009 \\
15 & Appias libythea & 1 & 0.001 & -6.9 & -0.004 \\
16 & Locusta migratoria & 13 & 0.008 & -4.82 & -0.040 \\
17 & Valanga nigricornis & 5 & 0.003 & -5.8 & -0.018 \\
18 & Tettigridea lateralis & 2 & 0.001 & -6.9 & -0.009 \\
19 & Crocothemis servilia & 4 & 0.003 & -5.8 & -0.015 \\
20 & Orthertrum Sabina & 7 & 0.004 & -5.52 & -0.024 \\
21 & Ischnura senegalensis & 7 & 0.004 & -5.52 & -0.024 \\
22 & Lucilia sericata & 2 & 0.001 & -6.9 & -0.009 \\
23 & Musca domestica & 4 & 0.003 & -5.8 & -0.015 \\
24 & Coccinella transversalis & 4 & 0.003 & -5.8 & -0.015 \\
25 & Coccinella Sp. & 1 & 0.001 & -6.9 & -0.004 \\
26 & Hierudula vitrea & 3 & 0.002 & -6.21 & -0.012 \\
& $\quad$ Jumlah & 1580 & & & -1.68 \\
\hline
\end{tabular}

Indeks keragaman serangga adalah :

$$
\begin{aligned}
& H^{\prime}=-\sum i=1 P i \cdot \ln P i \\
& H^{\prime}=-(-1.68) \\
& H^{\prime}=1.68
\end{aligned}
$$

Nilai keragaman serangga diurnal di kawasan kampus Universitas Muhammadiyah Aceh adalah 1,68. Berdasarkan Indeks keragaman Shannon Wiener apabila nilai 1,5 - 3,5 maka

$$
\begin{aligned}
E^{\prime} & =\frac{H^{\prime}}{\ln S} \\
E^{\prime} & =\frac{1.68}{\ln 26} \\
E^{\prime} & =\frac{1.68}{3.25} \\
E^{\prime} & =0.51
\end{aligned}
$$

Kemerataan serangga diurnal di 0,51 artinya bahwa distribusi jumlah kawasan kampus Universitas

Muhammadiyah Aceh indeks kemerataan keragaman sedang. Jadi indeks keragaman serangga diurnal di kawasan kampus Universitas Muhammadiyah Aceh tergolong rendah. Selanjutnya dihitung juga kemerataan jenis. 
masing - masing stasiun penelitian relatif

Hasil penelitian yang telah dilakukan di kawasan kampus Universitas Muhammadiyah Aceh terhadap serangga diurnal baik serangga yang beraktifitas dipermukaan tanah, di udara dan di pepohonan dengan empat cara yaitu dengan menggunakan jala serangga (insect net), perangkap sumur (pitfall trap), areal bait trap dan alat hisap (aspirator) diperoleh serangga diurnal sebanyak 1580 individu yang terdiri dari 8 Ordo, 17 familia dengan 26 jenis.

Keberadaan serangga diurnal sangat berbeda antara satu stasiun pengamatan dengan stasiun lainnya. Stasiun pengamatan I merupakan lingkungan dalam kampus Universitas Muhammadiyah Aceh, ditinjau dari luas area penelitian stasiun I lebih luas dibandingkan dua stasiun pengamatan lainnya namun lokasi stasiun mencakup bagunan untuk aktivitas kampus dan hanya sedikit lokasi yang di tumbuhi rumput atau tumbuhan semak sebagai habiat serangga pada umumnya, sehingga sulit serangga untuk bertahan hidup. Hal ini sesuai dengan pendapat Jumar yang menyatakan bahwa "populasi serangga akan menurun jika keadaan makanan tidak cocok (Jumar, 2000).

Stasiun pengamatan I di peroleh 6 Ordo, 8 familia, dengan 13 jenis serangga diurnal. Lima (5) jenis berasal dari Ordo Hymenoptera familia Formicidae dan
Jurnal Jeumpa, 8 (2) Juli-Desembaer 2021 terdistribusi secara merata.

Apidae, 2 dari Ordo Lepidoptera familia Nymphalidae, 2 dari Ordo Orthoptera familia Acrididae, 2 dari Ordo Hemiptera familia Pentatomidae dan Lygaeidae, 1 dari Ordo Diptera familia Muscidae dan 1 dari Ordo Odonata familia Libellulidae. Jumlah individu yang diperoleh pada stasiun pengamatan ini adalah 453 individu.

Pengamatan di stasiun II ditemukan pada stasiun pengamatan II terdiri 8 Ordo, 15 familia, dengan 24 jenis serangga diurnal, terdiri dari 7 jenis berasal dari Ordo Hymenoptera familia Formicidae, Apidae, dan Perilampidae, 4 dari Ordo Lepidoptera family Nymphadae dan Pieridae, 3 dari Ordo Orthoptera familia Acrididae dan Tettrigidae, 3 dari Ordo Odonata familia Libellulidae dan Coenagrionidae, 3 dari Ordo Hemiptera familia Alididae dan Coreidae, 2 dari Ordo Coleoptera familia Coccinellidae, 1 Ordo Mantodea familia Mantidae dan 1 Ordo Diptera familia Muscidae. Jumlah individu yang diperoleh pada stasiun pengamatan ini adalah 860 individu.

Stasiun pengamatan II berada di sebelah Selatan. Di tinjau dari luas area stasiun pengamatan II lebih luas di banding dengan dua stasiun lainnya dan banyak ditumbuhi tumbuhan semak, beberapa pohon, juga area persawahan yang merupakan habitat serangga pada umumnya sehingga mendukung kehidupan serangga 
untuk tempat tinggal, mencari makan dan berkembang biak. Hal ini di buktikan dari keberadaan serangga diurnal yang relatif banyak dan sesuai dengan pendapat jumar “jika makanan tersedia dengan kualitas yang cocok dan kuantitas yang cukup maka populasi serangga akan bertambah (Jumar, 2000).

Stasiun III diperoleh terdiri 7 Ordo, 8 familia, dengan 12 jenis. Empat (4) jenis berasal dari Ordo Hymenoptera familia Formicidae dan Apidae, 2 jenis dari Ordo Lepidoptera familia Nymphalidae, 2 jenis dari Ordo Hemiptera familia Alydidae dan Lygaeidae, 1 jenis dari Ordo Odonata familia Libellulidae, 1 jenis dari Ordo Orthoptera familia Acrididae, 1 jenis dari Ordo Diptera familia Calliphoridae dan 1 jenis dari Ordo Coleoptera familia Coccinellida. Jumlah individu yang diperoleh pada stasiun pengamatan ini adalah 267 individu. Stasiun tiga berada dibagian Timur yang merupakan lokasi persawahan.

Berdasarkan pengumpulan data dan hasil analisis data diperoleh nilai indeks keragaman 1,68. Berdasarkan indeks Shannon Wiener nilai 1,68 tergolong dalam kriteria keragaman sedang dan memperoleh indeks kemerataan 0,51 artinya bahwa distribusi jumlah individu setiap jenis serangga diurnal di masing - masing stasiun penelitian relatif terdistribusi secara merata.
Selain dari kondisi lingkungan, faktor pH tanah, suhu dan kelembaban sangat mempengaruhi aktifitas serangga. Serangga hanya bisa berkembang biak pada $\mathrm{pH}$, suhu dan kelembaban yang sesuai. Serangga memerlukan suhu lingkungan yang berbeda - beda, hal inilah yang menyebabkan serangga tidak dapat bertahan hidup di sutu habibat tertentu. Adapun data fluktuansi faktor fisik cuaca dan tanah yang mendukung hasil penelitian adalah $\mathrm{pH}$ tanah 5.9, suhu udara $29^{\circ} \mathrm{C}$, suhu tanah $26^{\circ} \mathrm{C}$, dan kelembaban udara $68 \%$.

$$
\text { Kehidupan serangga sangat }
$$
dipengaruhi oleh kelembaban dara dan suhu yang di sekitarnya. Serangga memerlukan uap air untuk mengatur temperatur dan tekanan tubuh yang seimbang dengan lingkungan. Masuknya panas ke habiatat serangga akan mengubah temperature tubuh serta benda - benda yang ada di sekitarnya. Pengaruh temperatur akan mengubah batas toleransi hewan untuk melakukan reproduksi, tumbuh, beradaptasi, dan bertahan hidup. Suhu lingkungan yang berada pada titik $29{ }^{\circ} \mathrm{C}$ merupakan temperatur optimum bagi serangga.

Diantara semua spesies yang didapatkan, familia Formiciadae merupakan serangga yang paling dominan di kawasan kampus UNMUHA. Banyaknya spesies tersebut di dukung oleh keadaan lingkungan yang sesuai untuk kehidupan semut, dimana 
semut banyak di temukan di daerah rumput atau semak dan di pepohonan.

Penelitian ini juga di peroleh hasil yang sama dengan penelitian yang dilakukan oleh Niken Subekti tentang keragaman jenis serangga di hutan tinjomoyo memiliki luas tahan $57 \mathrm{Ha}$ dan mendapatkan hasil penelitian bahwa keragaman jenis serangga di hutan tinjomoyo sangat kurang, hal ini dibuktikan dengan hanya ditemukan 19 jenis serangga dengan indeks nilai penting 3,18-11,89\% serta nilai densitas 0-6,42. Penelitian serupa juga dilakukan oleh Vita Shilviana, dkk. mengenai keragaman serangga di taman Aspari Surabaya dan memperoleh hasil 5 familia 2 dari Ordo dengan nilai keragaman 1,52 (Niken, 2015).

Serangga diurnal yang terdapat di kawasan kampus Universitas

\section{KESIMPULAN}

Dari hasil pengamatan yang telah dilakukan mengenai keragaman jenis serangga diurnal dikawasan kampus Universitas Muhammadiyah Aceh sebagai media pembelajaran zoologi invertebrata dapat disimpulkan bahwa jenis serangga diurnal yang terdapat dikawasan kampus Universitas Muhammadiyah Aceh 26 jenis yaitu Semut Gula (Pheidole Sp.), Semut Hitam 1 (Iridomermex Sp.), Semut Api (Solenopsis Sp.), Semut Hitam 2 (Formica $\mathrm{Sp})$, Semut Gila (Paratrecina longicornis),
Jurnal Jeumpa, 8 (2) Juli-Desembaer 2021 Muhammadiyah Aceh dapat dijadikan media pembelajaran zoologi invertebra dengan menggunakan buku saku. Buku saku ini di dasarkan dari keberadaan jumlah individu. Buku saku yang dimaksud berisi deskripsi dan klasifikasi dari serangga diurnal hasil penelitian yang terdapat di kawasan kampus Universitas Muhammadiyah Aceh, sehingga dapat memudahkan mahasiswa untuk mengenal serangga di kawasan kampus yang di jadikan tempat pengamatan serangga. Buku saku yang dimaksud dapat dijadikan sebagai media pembelajaran untuk memperoleh imfo tentang serangga serangga diurnal yang terdapat dikawasan kampus Universitas Muhammadiyah Aceh (UNMUHA).

Lebah (Apis andreniformis), Tawon (Perilampidae 1), Walang sangit (Leptocorisa acuta), Kutu ubi jalar (Physomerus grossipes), Bapak Pucung (Dysdercuc cingulatus), Kepik hijau (Nezara viridula), Kupu - kupu Orange (Acraea violae), Kupu - kupu Biduri (Danaus chrysippus) Kupu - kupu Putih Hijau (Appias olferma) Kupu - kupu Putih Hitam (Appias libythea), Belalang Coklat (Locusta migratoria), Belalang kayu (Valanga nigricornis), Belalang Runcing (Tettrigridae lateralis), Capung Sawah (Crocothemis servilia), Capung Hijau 
Jurnal Jeumpa, 8 (2) Juli-Desembaer 2021

(Orthertrum Sabina), Capung Jarum (Ischnura senegalensis), Lalat Hijau (Lucilia sericata), Lalat Rumah (Musca domestica), Kumbang koksi 1 (Coccinella transversalis), Kumbang koksi 2 (Coccinella Sp.), dan Belalang sembah (Hierudula vitrea). Keragaman serangga diurnal dikawasan kampus Universitas

\section{DAFTAR PUSTAKA}

Jasin, Maskoeri.Zoologi Invertebrata. Surabaya : Sinar Wijaya, 1987.

Jumar. Entomologi Pertanian. Jakarta : Rineka Cipta, 2000.

Michael .Metode Ekologi Untuk Penyelidikan Lapangan dan Laboratorium Indonesia. Jakarta: UI Press, 1994.

Michael .Metode Ekologi Untuk Penyelidikan Lapangan dan Laboratorium Indonesia. Jakarta: UI Press, 1994.

Oemar, Hamalik. Media Pendidikan. Bandung:Tarsito, 1989.

Subekti, Niken. Keragaman jenis serangga di hutan tinjomoyokota Semarang Jawa Tengah. 2015

Sugiyono. Statistik untuk Penelitian. Bandung: Alfabeta. 2011.

Supriyono. Akuntansi Biaya Pengumpulan Biaya dan Penentuan Harga Pokok, Buku 1 Edisi 2. Yogyakarta: BPFE. 2011.
Muhammadiyah Aceh tergolong sedang, hal ini dibuktikan dengan indeks keragaman bernilai 1,68. Keragaman serangga diurnal di kawasan kampus Universitas Muhammadiyah Aceh dapat dijadikan media pembelajaran zoologi invertebrata dengan menggunakan buku saku. 